\title{
A Survey Study of Autonomous Learning by Chinese Non-English Major Post-graduates
}

\author{
Jianping Xu \\ School of Foreign languages, Jiangsu University \\ Zhenjiang 212013, China \\ E-mail: xujp@ujs.edu.cn
}

\begin{abstract}
This thesis reports a survey study of the autonomous L2 learning by 100 first-year non-English-major Chinese post-graduates via the instruments of a questionnaire and semi-structured interview after the questionnaire. It attends to address the following research question: To what extent do Chinese postgraduate students conduct autonomous L2 learning? It was found that the overall degree of the postgraduates' autonomous English learning is not so satisfactory as expected. Much needs to be done in order to have a deeper insight into the essence of the learner autonomy and make contributions to the realization of learner autonomy for postgraduates.
\end{abstract}

Keywords: Autonomous learning, Survey, Non-English major post-graduates

\section{Introduction}

The factor which prompted me to do a research on autonomous L2 learning by Chinese postgraduates is my observation in person that although the autonomous L2 learning has been required by the curriculum and highly highlighted by both researchers and practitioners, it is a path seldom treaded by many of the Non-English major postgraduates. Being a would-be researcher, non-English postgraduates are required to improve on their English competence via autonomous learning, and they have already been equipped with the essential linguistic groundwork as well as more free time to deal with the autonomous L2 learning. Yet we don't how to what extent they are able to conduct autonomous L2 learning. Such an observation ensured me of the need to conduct the present study.

\section{Literature review}

At first, it is a necessity to explore the basic concepts of learner autonomy by reviewing the major definitions and features of learner autonomy.

\subsection{Definitions of Learner Autonomy}

Holec (1981) defines autonomous learning as "the ability to take charge of one's own learning". And he elaborates this basic definition as follows: determining the objectives; defining the contents and progressions; selecting methods and techniques to be used; monitoring the procedure of acquisition (rhythm, time, place, etc.) and evaluating what has been acquired.

Little (1991) argues that "Essentially, autonomy is a capacity---for detachment, critical reflection, decision-making and independent action. The capacity for autonomy will be displayed both in the way the learner learns and in the way he or she transfers what has been learned to wider contexts."

From the above definitions, we should make clear that Learner autonomy is learners' capacity that is exercised and displayed during the process of autonomous learning, while autonomous learning is an act of learning whereby motives learners consciously make best decisions about their own learning. Learning alone is often seen as a necessary element of autonomous learning.

\subsection{Individual differences in English learning}

It is obvious that not all the students are successful learners in English because of such individual differences as their linguistic competence, learning motivations, different learning styles and different learning strategies.

\subsubsection{Learner beliefs}

Learner beliefs (Richardson, 1996), are "psychologically held understandings, premises, or propositions about the world that are felt to be true".

Corder (1967) said, "Given motivation, anyone can learn a language." The phrase brings out the importance of motivation and the way it can overcome unfavorable circumstances in other aspects of language learning.

Self-confidence also plays an important role in language learning. All things being equal, the self-confident person 
tends to be a more successful learner, because such people have the advantage of not fearing rejection and are therefore more likely to put themselves in learning situations and do so repeatedly.

\subsubsection{Learning strategies}

Almost every student is using his or her preferred learning strategies consciously or unconsciously in the procedure of English learning. Learning strategy is firmly believed to be the key to promoting AEL (Wenden 1985, cited in Brown 1987:84). When students are inhibited from using their favorite strategy, it is impossible for them to learn language efficiently.

(1)Cognitive Strategies

According to O'Malley (1990: 44), cognitive strategies "operate directly on incoming information, manipulating it in ways that enhance learning. "Learners may use any or all of the following cognitive strategies (Cook, 1993:1 143-115):

(2) Meta-cognitive Strategies

According to Wenden (1998:34), "meta-cognitive knowledge includes all facts learners acquire about their own cognitive processes as they are applied and used to gain knowledge and acquire skills in varied situations". In a sense, "they are strategies about learning rather than learning strategies themselves" (Cook, 1993:114).

\section{Methodology}

\subsection{Research questions}

The present study intends to address the following research question about to what extent do Chinese postgraduate students conduct autonomous L2 learning, which will be discussed from the following five aspects.

1). What are their beliefs in autonomous L2 learning?

2). Can they determine their objectives of autonomous $L 2$ learning?

3). Can they implement the strategies of autonomous L2 learning?

4). Can they monitor their process of autonomous L2 learning?

5). Can they evaluate the efficacy of their autonomous L2 learning?

\subsection{Subjects}

The subjects of the present study are the 100 first-year non-English postgraduates from Jiangsu University. All of them have passed TEM 4/6, and postgraduate students are faced with more academic reading and writing in English, which should be done with their own efforts via AL.

\subsection{Instruments}

The quantitative data in this research were collected from one revised questionnaire. The theoretical foundations of the revised questionnaire are based on Xu Jinfen. et al (2004) definition of the English learning autonomy in the English teaching context in China, Schunk D.H \& Zimmerman B. J.'s (1994) ideas on major research framework of learner autonomy and Littlewood's (1996) opinions on components of autonomy.

\section{Insert Table 3.1 here!}

\subsection{Interview}

After the questionnaire investigation, interviews were conducted to add a qualitative research support the whole investigation, from which the qualitative data of the research were acquired.

\subsection{Data collection and Data analysis}

Data were collected during regular class time over a one-week span, which could be roughly divided into three phases. Phase one was the treatment for the students. In this phase, the students were required to understand the purpose of the author's survey. Phase two was answering the questionnaires. Phase three was in the process of the interviews.

The questionnaire measures the degree of non-major English postgraduates' L2 learning on a five-point Likert Scale, which ranges from 1 to 5 . Postgraduates were asked to judge whether the statements were true for them. They could write A, B, C, D or E according to their own specific case. They got 5 points to 1 point for each A to each E.

As is stated previously, the qualitative data come from the semi-structured interviews, which were transcribed by the research. The transcription was analyzed to find in-depth understanding of the subjects' beliefs and behaviors of their autonomous L2 learning.

\section{Results and Discussions}

This chapter provides the results of the study mainly from the descriptive analyses of students' autonomous English learning competence. 
As shown in Table 4.1, the mean value of the responses to these five areas was below the medium level. Among them, the average mean of the postgraduates' beliefs in autonomous L2 learning was the highest (Mean=3.39). The average mean of the postgraduates' competence of evaluating the autonomous L2 learning was the lowest(Mean=3.10).

\section{Insert Table 4.1 here!}

In order to gain a better understanding of postgraduates' autonomous L2 learning situation, these five specific areas are examined respectively in the following tables.

\subsection{Believing in autonomous L2 learning}

Table 4.2 illustrates the frequencies, means and standard deviations of their beliefs in autonomous L2 learning.

\section{Insert Table 4.2 here}

As seen in Item 1, in response to the question "clear idea of the postgraduates' teachers aims" (Item 1), and almost 33 students could have a clear idea of the teachers' teaching aims, and almost one out of five students were not sure about it, since the mean score was rather low (3.29). While considering whether they can have clear idea of the purpose of class activities set by the teachers in class (Item 2), only 44 students agreed with it, yet 36 students gave neutral answers together with 34 disagreements, the mean score was 3.30. Responses to item 3 shows that a majority of postgraduates realize the importance of making the teacher's aims and purposes their own (Item 3, Mean=4.03).

From Table 4.2, we know that most of students are not used to judging the teaching efficiency (Item 5, Mean=3.27), which may be illustrated by the following statements made by the subjects in the interview:

I'm not fully aware of the teachers' objectives in class. I can not identify the difference the purpose of L2 learning between college and graduate school ( subject 9)

I am not used to judging what my English teachers told and just do what the teachers ask.(subject 2)

The results in Table 4.2 leave instructors a most deep thinking question. In classroom, the role of teacher should not be a leader, but a facilitator - to help, to mediate, to encourage students to learn. There is a Chinese saying, "Give a man a fish and he eats for a day; teach him how to fish and he eats for a lifetime". In classroom teaching, the teacher should make his aims clearly understood by students, and use different strategies to make students fully and actively involved in the classroom activity.

Therefore, the teacher should have their own training about the teaching strategies, enforcing the importance of the aim of education.

\subsection{Determining the objectives of autonomous L2 learning}

Table 4.3 indicates the frequencies, means and standard deviations of determining the learning objectives.

\section{Insert Table 4.3 here}

As listed in Table 4.1, the overall average mean in this area was only 3.33 which indicated that a large number of postgraduates were incapable of determining their own postgraduates' English learning objectives because their learning habits are still affected by their habits of being college students. Based on the table 4.3, Specifically, it showed that the majority of postgraduates couldn't have a clear schedule for English autonomous learning after class (Item 5, Mean=3.31), which is their biggest obstacle in this area. As a postgraduate, the practical use of English in their majors, such as reading major literatures and paper writing in English, is particularly essential and crucial to them. However, the result of the research in this respect is far away from being satisfactory. It showed that not many postgraduates can have a clear idea of the demands for reading literature about their majors (item 8, Mean=3.12), and only 34 postgraduates have clear idea of finishing their paper in English (item 9, Mean=3.33) and only 20 of them have a clear idea of demands for communicating with foreign experts (item 10, Mean=3.08)

The followings are the interviews' main response to some interview questions:

In my research, I am used to reading Chinese articles and publishing my findings in Chinese journals firstly. I hardly want to publish my papers in foreign journals (subject 6)

I hardly participate the international conference, as a result, I have no chance to communicate with those foreign experts.(subject 15)

The results from Table 4.3 indicated that it is not so satisfactory for the majority of postgraduates in English autonomous L 2 learning. In particular, there is a long way to go in the practical impact of English on their majors' research. The main reason for this is impacted by the traditional language learning style. For years, Students are left with very little or no choice in learning English but to pass the diverse exams. Affected by this fact, the students don't have their own English learning plan besides assignments of the teachers and can't manage their time of autonomous L2 learning properly. As a result, they fail to change the role when they become postgraduates. 
Affected by the traditions of teacher-centeredness, students have long been exposed to traditional and authoritative learning environments so that they are accustomed to passiveness and dependence. Consequently, they begin to believe that to be a learner is to be dependent on a teacher, textbook and formal course. Meanwhile, the traditional curricula tend to only focus on imparting knowledge to students, which in some ways restraint students' initiative in language learning.

All in all, the traditional education system and the testing system in China are neither required, valued nor nurtured in the independence and autonomy learning. We postgraduates had best change the role in autonomous L2 learning.

\subsection{Defining their contents of autonomous L2 learning}

\section{Insert Table 4.4 here}

From the table 4.4, it was found in the survey that most of postgraduates have a comparatively good performance of selecting the proper reading (Item 12, Mean=3.62;). In contrast, they have poor performance in the selecting communication and translating strategies (Item 13, Mean=3.12; Item 15, Mean=3.09 respectively)

Some postgraduates in the interview said in the followings:

In translating English into Chinese or Chinese into English, I hardly realize the differences in these two languages. Some translating skills can not be adopted consciously.(subject 4)

Besides, many postgraduates (22 disagreement and 45 neutral answers) were found not be able to do well in implementing the writing strategies (Item 14, Mean=3.36). The following is their response when asked they were not capable of using the writing strategies even if the traditional language testing system in China emphasized students' writing skills.

I find writing so troublesome; I disgust writing although there is writing task in the exam.(subject 3)

I found that I have nothing to say in writing. In my daily learning English, I am used to doing reading comprehension. (subject 13)

Finally the Item 11 indicated that students were not able to do well in implementing listening strategies with the average mean being 3.33. Comments in the qualitative study shed light on the use of it:

The listening material of the textbook is boring, so in listening classes of multimedia classrooms, I prefer watching English movies to practicing. (subject 19)

In a few words, learning how to learn is necessary in the modern society. The main task for instructors is to create opportunities for students making them in actual use. As far as communicating and translating strategies are concerned, most students seldom have the opportunity to communicate with foreigners. The English knowledge from textbooks should not neglect the competence of communication and translating.

\subsection{Monitoring the process of autonomous L2 learning}

\section{Insert Table 4.5 here}

From Table 4.5, it was not difficult to notice that we can see that some students (52) often evaluate the learning strategies to find out the ineffective ones and improve them (Item 21, Mean=3.43). However, they could not monitor the use of learning strategies well, especially the writing and communicating strategies, and the average means of them were at a lower level (Item 19, Mean=3.32; Item 16, Mean=3.18 respectively). Comparatively, the item (18) of reading strategies reflects a higher degree (3.53). Here are the general opinions of the interviewees:

I don't know how to monitor the use of learning strategies well, especially the communication, translating and writing strategies.(subject 24)

After four years of learning English in college, some postgraduates realize the importance of the English learning strategies in a real sense, however, it does not seem to reach the ideal situation in this respect since there is lack of strategies training. As for postgraduates, most of them have a certain foundation in L2 learning, it is not so important to impart knowledge into them as to enrich the ability of monitoring the use of strategies, and the full use after each strategy introduced is preferred. The lack of learning strategies can not only delay the process of learning, but cause the interests of learning. Hence, it is very urgent to equip learning strategies with students.

\subsection{Evaluating the efficacy of their autonomous L2 learning}

\section{Insert Table 4.6 here}

The students were found not willing to have a cooperative learning (Item 22, Mean=2.70 and Item 23, Mean=2.64). This may be attested by the following remarks made by the students in the interview:

Sometimes we have cooperative activities in class, but most of us don't enjoy them. For we think they are meaningless, dull and a waste of time. We gain little from such activities. (subject 11) 
A considerably large number of postgraduates were found able to actively read the research papers in English (Item 25, Mean=3.42). Unfortunately, most of them were passive in finishing their research papers in English (Item 26, Mean=2.69). As some of interviewees have mentioned in the interview:

In publishing my research papers, the Chinese journals are my first choices, for I have some difficulties in writing my papers in English. (subject 2)

In addition, they were able to notice the language errors during language learning and found out the reasons for them (Item 27, Mean=3.31).

From Table 4.6, we can draw a conclusion that postgraduates are generally incompetent to evaluate their autonomous L2 learning. As a result, we English teachers should create more opportunities for cooperative learning, and hold more English activities for them to practice their English. Teachers try to foster their communicative ability, while students prefer giving response together. When writing compositions, some students can consciously apply the newly got knowledge into practice and make use of the available learning sources.

\section{Conclusion}

Base on the survey study, it was found that the overall degree of the postgraduates' autonomous English learning is not so satisfactory as expected. They have no very definite motivation and objectives of autonomous L2 learning in the stage of being postgraduates. What is more, they fail to be aware of the significance and the role of English in their major research. Meanwhile, most of postgraduates are so passive in cooperative learning and English activities, such as exchanging with foreign experts and paper writing in English in the foreign journals.

All in all, much needs to be done in order to have a deeper insight into the essence of the learner autonomy and make contributions to the realization of learner autonomy for postgraduates.

\section{References}

Benson, P. (1997). The philosophy and politics of learner autonomy. (18-34) [C]. In P. Benson \& P. Voller (Eds.), Autonomy and independence in language learning. London: Longman.

Broady, E. \& Kenning, M. (1996) Promoting Learner Autonomy in university Language Teaching. London:

Candy, P. (1991). Self-direction for lifelong learning [M]. San Franciso: Jossey-Bass Inc Publishers.

Chan,V. (2001). Readiness for learner autonomy: what do our learners tell us?(505-518). Teaching in Higher Education.

Cohen, A.D. (2000). Strategies in Learning and Using a Second Language. Beijing: Foreign Language Teaching and Research Press.

Cotterall, S. (2000). "Promoting Learner Autonomy Through the Curriculum; Principles for Designing Language Courses"(4):109-117. ELT Journal.

Dickinson, L. (1987). Self-instruction in Language Learning. Cambridge: Cambridge University Press.

Hedge, T. (2000). Teaching and Learning in the Language Classroom. Oxford: Oxford University Press.

Holec, H. (1981). Autonomy and Foreign Language Learning. Oxford: Pergamon Press.

Jinfen Xu. (2004). The Theory and Practice of Modern Teaching of Foreign Language.Huazhong University of Science and Technology. Wu Han, Hubei.

Littlewood, W. (1996). "Autonomy": an anatomy and a framework. (4)427-435 [J]. System.

Littlewood, W. (1999). "Defining and Developing Autonomy in East Asian Context”(1):71-94. [J]. Applied Linguistics.

McDevitt, B. (1997). Learner autonomy and the need for learner training (6):34-39. Language Learning Journal.

Schunk D. H \& Zimmerman B.J. (1994). self-regulation of learning and performance: issues and educational applications. Lawrence: Lawrence Erlbaum Associates publishers.

Wenden, A.L.\& Rubin, J. (1987). Learner strategies in language learning. New Jersey: Prentice Hall.

\section{Appendices}

\section{Appendix 1 English Majors' Autonomy Competence Questionnaire}

Your choices should be from A to E. A means completely true with me; B means usually true with me; C means sometimes true with me; D means not usually true with me and E means never true with me at all.

1. I have a clear idea of the postgraduates' teachers' teaching aims.

2. I have a clear idea of the purpose of class activities set by the teachers in class.

3. I think I can successfully make the teachers' aims and purposes their own 
4. I always correctly judge the teaching efficiency.

5. I am able to have clear schedule of English autonomous learning after class

6. I am able to plan the study time well for English learning.

7. I have clear idea of the demands for spoken and written abilities for the postgraduates.

8. I have a clear idea of demands for reading literature about my major.

9. I have a clear idea of demands for paper writing in English

10. I have a clear idea of demands for communicating with foreign experts orally.

11. I can implement appropriate listening strategies consciously in listening.

12. I can implement appropriate reading strategies consciously in reading

13. I can implement appropriate communicating strategies consciously in a conversation

14. I can implement appropriate writing strategies consciously in writing.

15. I can implement appropriate translating strategies consciously in translating.

16. I can monitor the use of communication consciously and critically in a conversation

17. I can monitor the use of listening strategies consciously and critically in listening exercise.

18. I can monitor the use of reading strategies consciously and critically in reading exercise

19. I can monitor the use of writing strategies consciously and critically in writing exercise

20. I can monitor the use of translating strategies consciously and critically in translating exercise.

21. I am able to use other more appropriate strategies after I had identified the strategies were not appropriate.

22. I actively look for opportunities to practice English with my classmates after class.

23. I actively look for opportunities to practice English with my teachers or foreigners after class.

24. I actively look for opportunities to participate in a variety of English activities after class.

25. I actively read my research papers in English.

26. I actively finish my research papers in English.

27. I am able to find out the reasons for language errors and take measures to correct them

\section{Appendix 2 Interview}

1. I am aware of the teachers' objectives in class and different purpose of L2 learning between college and graduate school.

2. In research I prefer Chinese journals to English ones.

3. I like to exchange foreign experts in my research field.

4. In translating I can have a definite idea of the difference between English and Chinese.

5. I like writing in English.

6. I know how to monitor the use of learning strategies well. especially the communication, translating and writing strategies.

7. I would like to cooperate with others to learn English.

Table 3.2. The categories of the questionnaire items

\begin{tabular}{|l|c|c|}
\hline \multicolumn{1}{|c|}{ Category } & $\begin{array}{c}\text { Total } \\
\text { items }\end{array}$ & Item number in the questionnaire \\
\hline Beliefs in autonomous learning & 4 & $1,2,3,4$ \\
\hline Determining the objectives & 6 & $5,6,7,8,9,10$ \\
\hline Implementing the learning strategies & 5 & $11,12,13,14,15$ \\
\hline Monitoring the process of autonomous L2 learning & 6 & $16,17,18,19,20,21$ \\
\hline Evaluating the efficacy of autonomous L2 learning & 7 & $22,23,24,25,26,27,28$ \\
\hline
\end{tabular}


Table 4.1. Average mean of all categories of overall picture of the postgraduates' AL

\begin{tabular}{|l|l|c|c|c|}
\hline \multicolumn{1}{|c|}{ Average mean of all the 5 categories } & $\mathrm{N}$ & Mean & SD \\
\hline Category 1 & Believing in autonomous L2 learning & 100 & 3.35 & .44 \\
\hline Category 2 & Determining the learning objectives & 100 & 3.39 & .50 \\
\hline Category 3 & Implementing the strategies & 100 & 3.33 & .46 \\
\hline Category4 & Monitoring the process & 100 & 3.58 & .38 \\
\hline Category 5 & Evaluating the efficacy & 100 & 3.36 & .43 \\
\hline
\end{tabular}

Table 4.2 Average means of their beliefs in autonomous L2 learning

\begin{tabular}{|c|c|c|c|c|c|c|c|c|}
\hline \multirow{2}{*}{ Items } & \multirow{2}{*}{ content } & \multicolumn{5}{|c|}{ Measuring level } & \multirow{2}{*}{ Mean } & \multirow{2}{*}{ S.D } \\
\hline & & 5 & 4 & 3 & 2 & 1 & & \\
\hline 1 & $\begin{array}{l}\text { Clear idea of the postgraduates' teachers teaching } \\
\text { aims }\end{array}$ & 1 & 32 & 35 & 19 & 13 & 3.29 & .913 \\
\hline 2 & $\begin{array}{l}\text { Clear idea of the purpose of class activities set by } \\
\text { the teachers in class. }\end{array}$ & 5 & 39 & 36 & 20 & 12 & 3.30 & .807 \\
\hline 3 & $\begin{array}{l}\text { Knowing the importance of making the teachers' } \\
\text { aims and purposes their own. }\end{array}$ & 31 & 52 & 9 & 4 & 4 & 4.03 & .936 \\
\hline 4 & Correctly judging the teaching efficiency & 4 & 22 & 39 & 25 & 10 & 3.27 & .885 \\
\hline
\end{tabular}

Table 4.3 Average means of determining the objectives of autonomous L2 learning

\begin{tabular}{|c|c|c|c|c|c|c|c|c|}
\hline \multirow{2}{*}{$\begin{array}{l}\text { Ite } \\
\mathrm{ms}\end{array}$} & \multirow{2}{*}{ Content } & \multicolumn{5}{|c|}{ Measuring level } & \multirow{2}{*}{ Mean } & \multirow{2}{*}{ S.D } \\
\hline & & 5 & 4 & 3 & 2 & 1 & & \\
\hline 5 & $\begin{array}{l}\text { Having clear schedule of English autonomous } \\
\text { learning after class }\end{array}$ & 8 & 30 & 37 & 23 & 2 & 3.31 & .895 \\
\hline 6 & Being able to plan the study time well & 5 & 45 & 30 & 16 & 4 & 3.32 & .723 \\
\hline 7 & $\begin{array}{l}\text { Clear idea of the demands for written and spoken } \\
\text { abilities }\end{array}$ & 3 & 31 & 49 & 10 & 7 & 3.24 & .817 \\
\hline 8 & $\begin{array}{l}\text { Clear idea of demands for reading literature about } \\
\text { my major }\end{array}$ & 5 & 30 & 45 & 13 & 7 & 3.12 & .896 \\
\hline 9 & Clear idea of demands for paper writing in English & 4 & 30 & 51 & 10 & 5 & 3.33 & .711 \\
\hline 10 & $\begin{array}{l}\text { Clear idea of demands for communicating with } \\
\text { foreign experts orally }\end{array}$ & 5 & 15 & 55 & 18 & 7 & 3.08 & .849 \\
\hline
\end{tabular}

Table 4.4. Average mean of implementing appropriate learning strategies

\begin{tabular}{|c|c|c|c|c|c|c|c|c|}
\hline \multirow{2}{*}{ Items } & \multirow{2}{*}{ Content } & \multicolumn{5}{|c|}{ Measuring level } & \multirow{2}{*}{ Mean } & \multirow{2}{*}{ S.D } \\
\hline & & 5 & 4 & 3 & 2 & 1 & & \\
\hline 11 & $\begin{array}{l}\text { Implementing appropriate listening strategies } \\
\text { consciously in listening }\end{array}$ & 5 & 40 & 49 & 4 & 2 & 3.33 & .714 \\
\hline 12 & $\begin{array}{l}\text { Implementing appropriate reading } \\
\text { strategies consciously in reading }\end{array}$ & 3 & 59 & 31 & 5 & 2 & 3.62 & .647 \\
\hline 13 & $\begin{array}{l}\text { Implementing appropriate communication } \\
\text { strategies consciously in a conversation }\end{array}$ & 2 & 21 & 62 & 10 & 5 & 3.12 & .755 \\
\hline 14 & $\begin{array}{l}\text { Implementing appropriate writing } \\
\text { strategies consciously in writing }\end{array}$ & 3 & 30 & 45 & 18 & 4 & 3.36 & .753 \\
\hline 15 & $\begin{array}{l}\text { Implementing appropriate translating } \\
\text { strategies consciously in translating }\end{array}$ & 5 & 40 & 45 & 8 & 2 & 3.09 & .753 \\
\hline
\end{tabular}


Table 4.5. Average means of the monitoring their process

\begin{tabular}{|c|c|c|c|c|c|c|c|c|}
\hline \multirow{2}{*}{ Items } & \multirow{2}{*}{ Content } & \multicolumn{5}{|c|}{ Measuring level } & \multirow{2}{*}{ Mean } & \multirow{2}{*}{ S.D } \\
\hline & & 5 & 4 & 3 & 2 & 1 & & \\
\hline 16 & $\begin{array}{l}\text { Monitoring the use of communication } \\
\text { consciously and critically in a conversation }\end{array}$ & 1 & 31 & 53 & 9 & 6 & 3.18 & .743 \\
\hline 17 & $\begin{array}{l}\text { Monitoring the use of listening strategies } \\
\text { consciously and critically in listening } \\
\text { exercise }\end{array}$ & 2 & 39 & 49 & 7 & 3 & 3.30 & .659 \\
\hline 18 & $\begin{array}{l}\text { Monitoring the use of reading strategies } \\
\text { consciously and critically in reading } \\
\text { exercise. }\end{array}$ & 3 & 57 & 31 & 7 & 1 & 3.53 & .731 \\
\hline 19 & $\begin{array}{l}\text { Monitoring the use of writing strategies } \\
\text { consciously and critically in writing exercise. }\end{array}$ & 4 & 46 & 41 & 7 & 2 & 3.32 & .700 \\
\hline 20 & $\begin{array}{l}\text { Monitoring the use of translating strategies } \\
\text { consciously and critically in translating }\end{array}$ & 3 & 47 & 40 & 9 & 1 & 3.30 & .666 \\
\hline 21 & $\begin{array}{l}\text { Often evaluating the learning strategies to } \\
\text { find out the ineffective ones and improve } \\
\text { them }\end{array}$ & 10 & 42 & 35 & 10 & 3 & 3.43 & .949 \\
\hline
\end{tabular}

Table 4.6 Average means of evaluating the efficacy of their autonomous L 2 learning

\begin{tabular}{|c|c|c|c|c|c|c|c|c|}
\hline \multirow{2}{*}{ Items } & \multirow{2}{*}{ Content } & \multicolumn{5}{|c|}{ Measuring level } & \multirow{2}{*}{ Mean } & \multirow{2}{*}{ S.D } \\
\hline & & 5 & 4 & 3 & 2 & 1 & & \\
\hline 22 & $\begin{array}{l}\text { Actively looking for opportunities to } \\
\text { practice English with my classmates out of class }\end{array}$ & 2 & 5 & 59 & 30 & 4 & 2.70 & .717 \\
\hline 23 & $\begin{array}{l}\text { Actively looking for opportunities to } \\
\text { practice English with my teachers or foreigners } \\
\text { out of class }\end{array}$ & 0 & 11 & 49 & 33 & 7 & 2.64 & .772 \\
\hline 24 & $\begin{array}{l}\text { Actively looking for opportunities to } \\
\text { participate in a variety of English activities out } \\
\text { of class }\end{array}$ & 0 & 10 & 45 & 38 & 7 & 2.59 & .753 \\
\hline 25 & Actively reading the research papers in English & 6 & 49 & 37 & 6 & 2 & 3.42 & .780 \\
\hline 26 & $\begin{array}{l}\text { Actively finishing my research papers in } \\
\text { English }\end{array}$ & 2 & 18 & 60 & 16 & 4 & 2.69 & .798 \\
\hline 27 & $\begin{array}{l}\text { Being able to find out the reasons for language } \\
\text { errors and take measures to correct errors }\end{array}$ & 4 & 43 & 45 & 6 & 2 & 3.31 & .812 \\
\hline
\end{tabular}

